\title{
Cancer in the Time of Coronavirus: A Call for Crisis Oncology Standards of Care
}

\author{
Amar H. Kelkar *(i) and Christopher R. Cogle $\mathbb{}$ \\ Division of Hematology and Oncology, Department of Medicine, College of Medicine, University of Florida, \\ Gainesville, FL 32610, USA; Christopher.Cogle@medicine.ufl.edu \\ * Correspondence: Amar.Kelkar@medicine.ufl.edu
}

Received: 1 July 2020; Accepted: 16 July 2020; Published: 17 July 2020

\begin{abstract}
Since the Coronavirus Disease 2019 (COVID-19) was identified as a global pandemic, health systems have been severely strained, particularly affecting vulnerable populations such as patients with cancer. In response to the COVID-19 pandemic, a variety of oncology specialty societies are making recommendations for standards of care. These diverse standards and gaps in standards can lead to inconsistent and heterogeneous care among governments, cancer centers, and even among oncologists within the same practice. These challenges highlight the need for a common nomenclature and crisis guidelines. For times of increased scarcity of resources, the National Academy of Medicine developed Crisis Standards of Care, defined as fairness, duty to care, duty to steward resources, transparency, consistency, proportionality, and accountability. However, we believe there is an urgent need to develop cancer-specific guidelines by convening a panel of experts from multiple specialties. These would be Crisis Oncology Standards of Care (COSCs) that are sensitive to both the individual cancer patient and to the broader health system in times of scarce resources, such as pandemic, natural disaster, or supply chain disruptions.
\end{abstract}

Keywords: Coronavirus; COVID-19; cancer; crisis; disaster preparedness

\section{Introduction}

In late 2019, the first cases of Severe Acute Respiratory Syndrome Coronavirus (SARS-CoV-2) of zoonotic origin and its human infection, known as Coronavirus Disease 2019 (COVID-19), were identified in the city of Wuhan, China, and spread rapidly across the world in a global pandemic [1]. This crisis has added considerable strain to already overtaxed health systems, distinctly impacting points of entry such as emergency departments and intensive care units (ICUs). While there are challenges in all fields of medicine under the public health threat of COVID-19, there are unique considerations in caring for the population of individuals with cancer given its older age, suppressed immune system (related to disease and treatment), and linkage to other risk factors such as tobacco smoking [2,3]. We believe the cancer population would benefit greatly from specific guidance on diagnostic, therapeutic, and surveillance management based on the severity of the public health crisis.

\section{Discussion}

Preliminary evidence from both China and Italy showed that cancer patients were more adversely affected by COVID-19 than standard patients [4,5]. Data in US cancer patients and an international multicenter study have also demonstrated more severe disease courses, especially after treatment with immunotherapy or surgery $[4,6]$. However, these data were contradicted by an 800 patient prospective cohort study by the UK Coronavirus Cancer Monitoring Project (UKCCMP) of patients with cancer and symptomatic COVID-19, which did not demonstrate increased odds of death from COVID-19 associated with anticancer therapies including cytotoxic chemotherapy, immunotherapy, hormone 
therapy, radiotherapy, surgery, or targeted therapy [7]. In this UKCCMP study, the strongest predictors of mortality were age, male sex, cardiovascular disease, and hypertension. Additionally, a retrospective observational study in New York demonstrated significantly higher mortality in patients with cancer and COVID-19 below the age of 50, but no significant different in patients above the age of 50 [6]. Due to the observational, imperfect nature of these datasets with numerous confounders, including notable variance between study groups, it remains difficult to clearly determine the significance of cancer and immunosuppression as risk factors for more severe disease courses of COVID-19. For the benefit of improved study quality, guidelines, and policymaking, 'principles for collaboration in the field of cancer and COVID-19' were outlined [8].

There is no historical precedent for management of novel checkpoint inhibitors, targeted therapies, and cellular therapies during pandemic events. However, insight can be drawn from the 2003 Severe Acute Respiratory Syndrome (SARS) outbreak in Toronto. Among the many emergency public health measures that were undertaken during that period, a key decision was to close transplant programs. Subsequently, there were concerns about the risks of resuming usual care and possible transmission of SARS from donors to recipients, and therefore a donor SARS screening tool was developed to support transplant programs. The introduction of this tool changed donor screening practices and no cases of SARS transmission from donor to recipient were or have been reported [9].

Before the COVID-19 pandemic, oncology standards of care were generally urgent, yet theoretically elective. However, guidance on cancer screening and diagnostic procedures have been considered a lower priority compared to cancer treatment. During the SARS-CoV-2 pandemic international guidelines, as well as state and local ordinances, limited "elective surgeries" inconsistently, resulting in delayed cancer diagnoses [10-12]. The IQVIA Institute for Human Data Science estimated that the first three months of the SARS-CoV-2 pandemic led to missing approximately 80,000 cases of cancer in the US alone [13]. Diagnostic delays may cause stage migration, where these missed cases will present with more advanced stage cancer at a later time point and will likely contribute to delayed and possibly more aggressive or expensive treatment [14].

The prevailing dogma is that cancer does not wait, so neither should our treatments. Studies have been mixed but seem to generally favor continued treatment during the pandemic. We must also consider cancer patients a vulnerable population due to the high financial and emotional cost of the underlying disease. However, these antineoplastic therapies are highly resource intensive. The intentional treatment with immunosuppressive therapies or potentially morbid surgery raises the question of whether it is ethical to increase the number of at-risk individuals when there are concerns regarding scarcity of resources, such as the availability of blood products, ICU beds, ventilators, personal protective equipment, and personnel.

A recent American Society of Clinical Oncology (ASCO) expert panel published recommendations for balancing the ethical treatment of individuals with cancer with the health of the population in the setting of resource scarcity [15]. The panel recommendations were based on the University of Pittsburgh's Allocation of Scarce Critical Care Resources During a Public Health Emergency and The Hastings Center's Ethical Framework for Health Care Institutions Responding to Novel Coronavirus SARS-CoV-2 (COVID-19) [16,17]. These recommendations have significant overlaps with the principles of the Crisis Standards of Care, defined by the National Academy of Medicine as fairness, duty to care, duty to steward resources, transparency, consistency, proportionality, and accountability [18]. There have also been several preliminary international guidelines published on the management of cancer patients in the setting of COVID-19 (Table 1) [15,19-21]. Additional guidelines published for specific countries and published in other languages, as well as specific disease states, have previously been summarized [22-25]. However, these triaged guidelines are mostly non-specific and may have contributed to significant inconsistency between providers and centers. This points to the larger unmet need of true Crisis Oncology Standards of Care (COSCs) that are sensitive to both the individual cancer patient and to the broader health system in times of scarce resources. The ASCO guidelines could serve as a preliminary framework for these COSCs [15]. 
Table 1. Published Preliminary COVID-19 Cancer Guidelines and Recommendations.

\begin{tabular}{ccc}
\hline Society & Recommendations & Links \\
\hline $\begin{array}{c}\text { ACR/ASBrS/NAPBC/ } \\
\text { NCCN/CoC Dietz 2020 }\end{array}$ & $\begin{array}{c}\text { Joint recommendations for } \\
\text { prioritization and treatment of patients } \\
\text { with breast cancer. }\end{array}$ & $\begin{array}{c}\text { https://www.facs.org/-/media/files/ } \\
\text { quality-programs/napbc/asbrs_napbc } \\
\text { coc_nccn_acr_bc_covid_consortium_ } \\
\text { recommendations.ashx }\end{array}$ \\
\hline ACS & $\begin{array}{c}\text { General background on cancer and } \\
\text { COVID-19, current advocacy efforts, } \\
\text { common questions and answers, and } \\
\text { patient information. }\end{array}$ & $\begin{array}{c}\text { https: } \\
\text { //www.cancer.org/about-us/what-we-do/ } \\
\text { coronavirus-covid-19-and-cancer.html }\end{array}$ \\
\hline ASCO Marron 2020 & Ethical considerations for resource \\
scarcity in cancer care. & $\begin{array}{c}\text { https://www.asco.org/sites/new-www. } \\
\text { asco.org/files/content-files/advocacy-and- } \\
\text { policy/documents/JCO.20.00960.pdf?cid= } \\
\text { DM48768bid=41686163 }\end{array}$ \\
\hline ASCO & $\begin{array}{c}\text { Recommendations for triage, diagnosis, } \\
\text { treatment, infection prevention, facility } \\
\text { management, clinical trials, and support } \\
\text { services with links. }\end{array}$ & $\begin{array}{c}\text { https://www.asco.org/sites/new-www. } \\
\text { asco.org/files/content-files/2020-ASCO- } \\
\text { Guide-Cancer-COVID19.pdf }\end{array}$ \\
\hline & Expert recommendations on &
\end{tabular}

Expert recommendations on management of chemotherapy, cellular

ASH therapies, and transplant for

hematologic malignancies and non-malignant diseases including thrombosis.

Recommendations for screening, ASTRO treatment, and follow-up of radiation pandemic.

https://www.hematology.org/covid-19

Recommendations on deferral or treatment with HSCT based on COVID-19 status of donor or recipient.

https://www.ebmt.org/sites/default/files/ 2020-04/EBMT-COVID-19-guidelines_v.6. $1 \% 282020-04-07 \% 29$.pdf

Recommendations for triage during the https://www.esmo.org/guidelines/cancer-

COVID-19 pandemic by tumor type, patient-management-during-the-covidstage, prioritization. 19-pandemic

\begin{tabular}{|c|c|c|}
\hline ESTRO & $\begin{array}{l}\text { General recommendations on treatment } \\
\text { and deferral with radiation therapy. }\end{array}$ & $\begin{array}{l}\text { https://www.estro.org/About/Newsroom/ } \\
\text { News/Radiotherapy-in-a-time-of-crisis }\end{array}$ \\
\hline NCCN Ueda 2020 & $\begin{array}{c}\text { Outline of recommendations for triage, } \\
\text { treatment decisions, ethical } \\
\text { considerations, and hospital } \\
\text { management. }\end{array}$ & $\begin{array}{c}\text { https://jnccn.org/view/journals/jnccn/18/ } \\
\text { 4/article-p366.xml?rskey=vYDEqI\& } \\
\text { result=1 }\end{array}$ \\
\hline SIOP & $\begin{array}{l}\text { Resource library, registry, and } \\
\text { collaboration space for COVID-19 } \\
\text { management in cancer. }\end{array}$ & $\begin{array}{l}\text { https://global.stjude.org/en-us/global- } \\
\text { covid-19-observatory-and-resource- } \\
\text { center-for-childhood-cancer.html }\end{array}$ \\
\hline SSO Bartlett 2020 & $\begin{array}{c}\text { Management of solid tumor surgeries } \\
\text { and neoadjuvant/adjuvant } \\
\text { chemotherapy including timing and } \\
\text { deferral during the COVID-19 } \\
\text { pandemic. }\end{array}$ & $\begin{array}{l}\text { https://link.springer.com/article/10.1245/ } \\
\text { s10434-020-08461-2 }\end{array}$ \\
\hline WBMT & $\begin{array}{l}\text { Brief recommendations regarding } \\
\text { transplant for hematologic malignancies } \\
\text { including potential need to delay } \\
\text { transplants in areas with endemic or } \\
\text { high frequency of COVID-19 infections. }\end{array}$ & $\begin{array}{c}\text { https: } \\
\text { //www.wbmt.org/wp-content/uploads/ } \\
\text { 2020/03/WBMT_COVID-19-2.pdf }\end{array}$ \\
\hline
\end{tabular}

Dietz 2020 [19], Marron 2020 [15], Ueda 2020 [20], and Bartlett 2020 [21]. ACR, American College of Radiology; ASBrS, American Society of Breast Surgeons; NAPBC, National Accreditation Program for Breast Centers; NCCN, National Comprehensive Care Network; CoC, Commission on Cancer; ACS, American Cancer Society; ASCO, American Society of Clinical Oncology; ASH, American Society of Hematology; ASTRO, American Society for Radiation Oncology; EBMT, European Society for Blood and Marrow Transplantation; ESMO, European Society for Medical Oncology; ESTRO, European Society for Radiotherapy and Oncology; SIOP, International Society of Pediatric Oncology; SSO, Society of Surgical Oncology; WBMT, Worldwide Network for Blood and Marrow Transplantation. 
To design COSCs, a task force of cancer control experts from multiple organizations would need to be brought together. They would first need to define common nomenclature to allow for a unified discussion, including terms like "essential" and "elective" procedures. The American Medical Association Code of Medical Ethics would need to be reviewed and expanded on to define triage principles and potentially specific clinical protocols in cancer care so that they can be applied fairly and consistently to all cancer patients [26]. Using the Code, these COSCs would need to define ethical allocation principles for both acute and chronic scarcity of personnel and product resources to avoid unequal practices between facilities. These could be expanded from the ASCO guidelines to include (1) modified sickest first (accounting for performance status and comorbidities), (2) life-years saved, and (3) modified youngest first (based on ability to tolerate oncologic therapies), while still considering utilitarian principles like maximizing number of lives saved, but avoiding first-come-first-serve allocation. Part of this ethical approach would need to prioritize urgency of treatment by histological type (e.g., acute promyelocytic leukemia or small-cell lung cancer), presence of emergent features (e.g., superior vena cava syndrome), and the resource intensity required for treatment (e.g., availability of oral chemotherapeutic options). COSCs would have to consider which clinical trials to continue and how to handle participant recruitment and management in situations of severe scarcity such as pandemics, natural disasters, and mass casualty events [27]. Oral therapies and telehealth follow-up may become more favored in these settings as trial recruitment falls [28]. One possible solution for clinical trials actively accruing patients could be to offer intermediate analysis of efficacy to justify continued study during high-risk periods; however, this could risk compromising future interpretation of these results, so this would need to be conducted thoughtfully and with input from scientific leaders and regulatory organizations. COSCs would also have to define triggers for initiation, such as interruptions to the chemotherapeutic supply chain, limited access to hospital beds or critical care services, staffing shortages or coverage by non-oncologic certified services, or inability to ensure safe management of treatment-related side effects [18]. Establishing COSCs would need to include discussion of situations in which potentially curative treatments, adjuvant therapies, or cellular therapies might be delayed and what supportive care should be used during the delay. Continuation or delay of cancer screenings needs to be discussed. Broad applications of telehealth and its reimbursement would need to be defined. Emergency approval of interstate licensure for oncology-certified clinicians for travel or telehealth may be an element of COSCs as well.

International consensus guidelines have largely focused on ethical allocation of resources to patients with COVID-19, but do not provide specific guidance on how individual centers would prioritize diagnostics, procedures, and treatments based on urgency [15]. One exception was the interim consensus guidance prepared by the Australasian Leukemia and Lymphoma Group (ALLG) and the National Centre for Infections in Cancer that presented responses based on disease phases [29]. Another, more focused, example by Kutikov and colleagues outlined risks of cancer progression with delay of treatment [30]. Many of our patients may never develop COVID-19 but may be adversely affected by delays or rationing of essential cancer care [31]. Thus, we developed a preliminary COSC decision support tool for grading oncology treatments that could help guide health systems and oncologists in their stewardship of resources during times of crisis (Table 2). With a tool like this, the oncology community could swiftly communicate the urgency levels of oncologic care that are indicated or must be withheld as a public health threat escalates or de-escalates. Additional dimensions to consider in a decision support tool would include age, immune suppression, medication and food security, caregiver support system, and other risk factors for susceptibility in public health threats. While this COSC decision support tool was designed to address issues on a local or national level, the World Health Organization or a conglomerate of international organizations could collectively apply these recommendations internationally with targeted recommendations for individual countries if needed. 
Table 2. Example Crisis Oncology Standards of Care (COSC) Decision Support Tool for Treatment Initiation.

\begin{tabular}{|c|c|c|c|c|c|}
\hline & & \multicolumn{4}{|c|}{ COSC Level } \\
\hline & & $\mathbf{A}$ & B & $\mathrm{C}$ & $\mathbf{D}$ \\
\hline & Definitions: & Chronic Care & Subacute Care & Urgent Care & Emergent Care \\
\hline \multirow{4}{*}{ Modality } & Cancer Prevention & $\begin{array}{ll}- & \text { Screening office visits } \\
- & \text { HPV testing } \\
- & \text { Screening chest } \\
\text { computed tomography } \\
\text { - } & \text { Screening prostate exam } \\
\text { and PSA testing } \\
\text { - } & \text { Routine } \\
& \text { skin examination }\end{array}$ & $\begin{array}{ll}\text { - } & \text { Surveillance colonoscopy } \\
\text { - } & \text { High-risk skin examination } \\
\text { - } & \text { Screening telehealth visits }\end{array}$ & & \\
\hline & Surgery/Procedural & - $\quad$ Screening colonoscopy & $\begin{array}{ll}- & \text { Excision of indolent mass } \\
- & \text { Presumed cancer biopsy } \\
- & \text { Surveillance telehealth visits }\end{array}$ & $\begin{array}{ll}- & \text { Excision of malignant mass } \\
- & \text { Debulking surgery } \\
- & \text { Abscess drainage }\end{array}$ & $\begin{array}{ll}\text { - } & \text { Threatened organ or limb } \\
\text { - } & \text { Typhlitis management } \\
\text { - } & \text { Spinal cord decompression } \\
\text { - } & \text { Fixation of } \\
& \text { orthopedic fracture }\end{array}$ \\
\hline & Radiation Therapy & Surveillance office visits & $\begin{array}{ll}- & \text { Adjuvant radiation therapy } \\
\text { - } & \text { Chemoembolization } \\
\text { - } & \text { Surveillance telehealth visits }\end{array}$ & $\begin{array}{ll}\text { - } & \text { Neoadjuvant } \\
\text { - } & \text { radiation therapy } \\
\text { Curative } \\
\text { - } \quad \text { radiofrequency ablation } \\
\text { Spinal cord or organ } \\
\text { impingement } \\
\text { radiation therapy } \\
\text { - } \quad \text { Central nervous system } \\
\text { stereotactic radiosurgery }\end{array}$ & $\begin{array}{l}\text { - } \quad \text { Superior vena cava syndrome } \\
\text { - } \quad \text { Severe bony pain and } \\
\text { symptom radiation therapy }\end{array}$ \\
\hline & Medical Oncology & Surveillance office visits & $\begin{array}{ll}- & \text { Adjuvant chemotherapy } \\
- & \text { Adjuvant } \\
\text { immuno-oncology therapy } \\
\text { - } & \text { Surveillance telehealth visits }\end{array}$ & $\begin{array}{ll}\text { - } & \text { Superior vena } \\
\text { cava syndrome } \\
\text { - } & \text { Visceral crisis } \\
\text { - } & \text { Neoadjuvant chemotherapy } \\
\text { - } & \text { Transfusion support }\end{array}$ & $\begin{array}{ll}- & \text { Febrile neutropenia } \\
- & \text { Tumor lysis syndrome } \\
- & \text { Hypercalcemia of malignancy } \\
\text { - } & \begin{array}{l}\text { Syndrome of inappropriate } \\
\text { antidiuretic hormone }\end{array}\end{array}$ \\
\hline
\end{tabular}


Table 2. Cont

\begin{tabular}{|c|c|c|c|c|c|}
\hline & \multicolumn{5}{|c|}{ COSC Level } \\
\hline & & A & B & C & D \\
\hline Definitions: & & Chronic Care & Subacute Care & Urgent Care & Emergent Care \\
\hline Malignant Hematology & 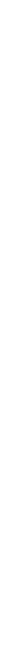 & Surveillance office visits & 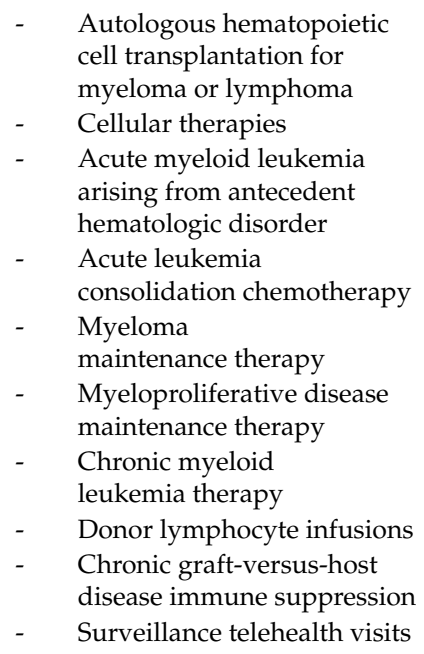 & $\begin{array}{ll}\text { - } & \text { Allogeneic hematopoietic } \\
\text { cell transplantation } \\
\text { - } & \text { Cellular therapies } \\
\text { - } & \text { Acute leukemia and blast } \\
\text { crisis induction and } \\
\text { re-induction therapy } \\
\text { - Myeloma induction and } \\
\text { re-induction therapy } \\
\text { - Sub-massive } \\
\text { pulmonary embolism } \\
\text { - Acute graft-versus-host } \\
\text { disease } \\
\text { immune suppression }\end{array}$ & $\begin{array}{ll}- & \text { Acute } \\
& \text { promyelocytic leukemia } \\
- & \text { Disseminated } \\
\text { intravascular coagulopathy } \\
- & \text { Leukostasis } \\
- & \text { Tumor lysis syndrome } \\
- & \text { Febrile neutropenia } \\
- & \text { Differentiation syndrome } \\
- & \text { Massive } \\
& \text { pulmonary embolism }\end{array}$ \\
\hline Clinical Trials & & Observational Studies & $\begin{array}{ll}\text { - } & \text { Interventional studies with } \\
\text { projected modest } \\
\text { improvement in } \\
\text { clinical outcomes } \\
\text { - } \quad \text { Clinical trial surveillance } \\
\text { imaging and } \\
\text { laboratory testing } \\
\text { - } \quad \text { Surveillance office visits } \\
\text { - } & \text { Surveillance telehealth visits }\end{array}$ & $\begin{array}{ll}\text { - } & \text { Interventional studies with } \\
\text { projected major } \\
\text { improvement in } \\
\text { clinical outcomes } \\
\text { - } \quad \begin{array}{l}\text { Interventional studies for } \\
\text { crisis-related treatments in }\end{array} \\
\text { the cancer population } \\
\text { - Clinical trial adverse } \\
\text { outcomes monitoring }\end{array}$ & $\begin{array}{l}\text { Interventional studies for } \\
\text { oncologic emergencies with } \\
\text { projected improvement in } \\
\text { clinical outcomes }\end{array}$ \\
\hline Cancer Survivorship & & $\begin{array}{l}\text { Surveillance imaging } \\
\text { Surveillance office visits }\end{array}$ & $\begin{array}{ll}\text { - } & \text { Surveillance } \\
& \text { laboratory testing } \\
\text { - } & \text { Surveillance telehealth visits }\end{array}$ & & \\
\hline
\end{tabular}

HPV, human papilloma virus; PSA, prostate-specific antigen. 


\section{Conclusions}

A mere four months ago, the leading ethical concerns were financial toxicity and disparities in access to oncology care [27]. While these issues remain, they are now complicated by a public health threat and the subsequent rationing of health care resources and delays in care. This current crisis serves as the impetus for developing guidelines for ethical rationing of resources in cancer care, but we believe that further expansion should include our COSC decision support tool and increased ethical guidance. COSCs would also need to consider prioritization by histology, chemotherapy and immunotherapy supply chain issues, scarcity of critical care resources, and clinical trials. More detailed COSC guidelines would enable the judicious use of cancer therapies, palliative care, supportive care, and end-of-life care during the current crisis and in the future.

Author Contributions: Conceptualization, A.H.K. and C.R.C.; methodology, A.H.K. and C.R.C.; investigation, A.H.K. and C.R.C.; validation, A.H.K. and C.R.C.; writing-original draft preparation, A.H.K.; writing-review and editing, A.H.K. and C.R.C.; visualization, A.H.K. and C.R.C. All authors have read and agreed to the published version of the manuscript.

Funding: This research received no external funding.

Conflicts of Interest: None of the authors have conflicts of interest to disclose.

\section{References}

1. Guan, W.-J.; Ni, Z.-Y.; Hu, Y.; Liang, W.-H.; Ou, C.-Q.; He, J.-X.; Liu, L.; Shan, H.; Lei, C.-L.; Hui, D.S.; et al. Clinical Characteristics of Coronavirus Disease 2019 in China. N. Engl. J. Med. 2020, 382, 1708-1720. [CrossRef] [PubMed]

2. Xia, Y.; Jin, R.; Zhao, J.; Li, W.; Shen, H. Risk of COVID-19 for cancer patients. Lancet Oncol. 2020, 21 , e180. [CrossRef]

3. Yeoh, C.B.; Lee, K.J.; Rieth, E.F.; Mapes, R.; Tchoudovskaia, A.V.; Fischer, G.W.; Tollinche, L.E. COVID-19 in the Cancer Patient. Anesth. Analg. 2020, 131, 16-23. [CrossRef] [PubMed]

4. Dai, M.; Liu, D.; Liu, M.; Zhou, F.; Li, G.; Chen, Z.; Zhang, Z.; You, H.; Wu, M.; Zheng, Q.; et al. Patients with cancer appear more vulnerable to SARS-COV-2: A multi-center study during the COVID-19 outbreak. Cancer Discov. 2020, 10, 783-791. [CrossRef] [PubMed]

5. Onder, G.; Rezza, G.; Brusaferro, S. Case-Fatality Rate and Characteristics of Patients Dying in Relation to COVID-19 in Italy. JAMA 2020, 323, 1775-1776. [CrossRef]

6. Miyashita, H.; Mikami, T.; Chopra, N.; Yamada, T.; Chernyavsky, S.; Rizk, D.; Cruz, C. Do patients with cancer have a poorer prognosis of COVID-19? An experience in New York City. Ann. Oncol. 2020, 1-2. [CrossRef]

7. Lee, L.Y.W.; Cazier, J.B.; Starkey, T.; Turnbull, C.D.; Kerr, R.; Middleton, G. COVID-19 mortality in patients with cancer on chemotherapy or other anticancer treatments: A prospective cohort study. Lancet 2020, 395, 1919-1926. [CrossRef]

8. Palmieri, C.; Palmer, D.; Openshaw, P.J.; Baille, J.K.; Semple, M.G.; Turtle, L. Cancer datasets and the SARS-CoV-2 pandemic: Establishing principles for collaboration. ESMO Open 2020, 5, e000825. [CrossRef]

9. Kumar, D.; Tellier, R.; Draker, R.; Levy, G.; Humar, A. Severe Acute Respiratory Syndrome (SARS) in a liver transplant recipient and guidelines for donor SARS screening. Am. J. Transpl. 2003, 3, 977-981. [CrossRef]

10. Al-Jabir, A.; Kerwan, A.; Nicola, M.; Alsafi, Z.; Khan, M.; Sohrabi, C.; O’Neill, N.; Iosifidis, C.; Griffin, M.; Mathew, G.; et al. Impact of the Coronavirus (COVID-19) pandemic on surgical practice-Part 2 (surgical prioritisation). In. J. Surg. 2020, 79, 233-248. [CrossRef]

11. Amit, M.; Tam, S.; Bader, T.; Sorkin, A.; Benov, A. Pausing cancer screening during the severe acute respiratory syndrome coronavirus 2pandemic: Should we revisit the recommendations? Eur. J.Cancer 2020, 134, 86-89. [CrossRef] [PubMed]

12. Dinmohamed, A.G.; Visser, O.; Verhoeven, R.H.A.; Louwman, M.W.J.; Van Nederveen, F.H.; Willems, S.M.; Merkx, M.A.W.; Lemmens, V.E.P.P.; Nagtegaal, I.D.; Siesling, S. Fewer cancer diagnoses during the COVID-19 epidemic in the Netherlands. Lancet Oncol. 2020, 21, 750-751. [CrossRef]

13. Aitken, M.; Kleinrock, M. Shifts in Healthcare Demand, Delivery, and Care During the COVID-19 Era: Tracking the Impact in the United States; IQVIA Institute for Human Data Science: Parsippany, NJ, USA, 2020. 
14. Sharpless, N.E. COVID-19 and cancer. Science 2020, 368, 1290. [CrossRef] [PubMed]

15. Marron, J.M.; Joffe, S.; Jagsi, R.; Spence, R.A.; Hlubocky, F.J. Ethics and Resource Scarcity: ASCO Recommendations for the Oncology Community During the COVID-19 Pandemic. J. Clin. Oncol. 2020, 38, 2201-2205. [CrossRef] [PubMed]

16. White, D.B. A Model Hospital Policy for Allocating Scarce Critical Care Resources. Available online: https://ccm.pitt.edu/?q=content/model-hospital-policy-allocating-scarce-critical-care-resourcesavailable-online-now (accessed on 24 April 2020).

17. Nancy, B.; Wynia, M.; Powell, T.; Hester, D.M.; Milliken, A.; Fabi, R.; Cohn, F.; Guidry-Grimes, L.K.; Watson, J.C.; Bruce, L.; et al. Ethical Framework for Health Care Institutions Responding to Novel Coronavirus SARS-CoV-2 (COVID-19) \& Guidelines for Institutional Ethics Services Responding to COVID-19: Managing Uncertainty, Safeguarding Communities, Guiding Practice. Available online: https://www.thehastingscenter. org/ethicalframeworkcovid19/ (accessed on 24 April 2020).

18. Hick, J.L.; Hanfling, D.; Wynia, M.K.; Pavia, A.T. Duty to Plan: Health Care, Crisis Standards of Care, and Novel Coronavirus SARS-CoV-2. NAM Perspect. 2020, 1-13. [CrossRef]

19. Dietz, J.R.; Moran, M.S.; Isakoff, S.J.; Kurtzman, S.H.; Willey, S.C.; Burstein, H.J.; Bleicher, R.J.; Lyons, J.A.; Sarantou, T.; Baron, P.L.; et al. Recommendations for prioritization, treatment, and triage of breast cancer patients during the COVID-19 pandemic. the COVID-19 pandemic breast cancer consortium. Breast Cancer Res. Treat. 2020, 181, 487-497. [CrossRef] [PubMed]

20. Ueda, M.; Martins, R.; Hendrie, P.C.; McDonnell, T.; Crews, J.R.; Wong, T.L.; McCreery, B.; Jagels, B.; Crane, A.; Byrd, D.R.; et al. Managing Cancer Care During the COVID-19 Pandemic: Agility and Collaboration Toward a Common Goal. J Natl. Compr. Cancer Netw. 2020, 18, 366-369. [CrossRef]

21. Bartlett, D.L.; Howe, J.R.; Chang, G.; Crago, A.; Hogg, M.; Karakousis, G.; Levine, E.; Maker, A.; Mamounas, E.; McGuire, K.; et al. Management of Cancer Surgery Cases During the COVID-19 Pandemic: Considerations. Ann. Surg. Oncol. 2020, 27, 1717-1720. [CrossRef]

22. Mauri, D.; Kamposioras, K.; Tolia, M.; Alongi, F.; Tzachanis, D.; Petricevic, B.; Chilingirova, N.; Mihaylova, I.; Tsakiridis, T.; Salembier, C.; et al. Summary of international recommendations in 23 languages for patients with cancer during the COVID-19 pandemic. Lancet Oncol. 2020, 21, 759-760. [CrossRef]

23. Uwins, C.; Bhandoria, G.P.; Shylasree, T.; Butler-Manuel, S.; Ellis, P.; Chatterjee, J.; Tailor, A.; Stewart, A.; Michael, A. COVID-19 and gynecological cancer: A review of the published guidelines. Int. J. Gynecol. Cancer 2020, 1-10. [CrossRef]

24. Chen, H.; Wu, X.; Wang, W.; Wang, Q. When cancer encounters COVID-19 in China: What have we suffered, experienced and learned. Jpn. J. Clin. Oncol. 2020, 50, 712-717. [CrossRef] [PubMed]

25. Raymond, E.; Thieblemont, C.; Alran, S.; Faivre, S. Impact of the COVID-19 Outbreak on the Management of Patients with Cancer. Target. Oncol. 2020, 15, 249-259. [CrossRef] [PubMed]

26. Crisis Standards of Care: Guidance from the AMA Code of Medical Ethics. Available online: https://www. ama-assn.org/delivering-care/ethics/crisis-standards-care-guidance-ama-code-medical-ethics (accessed on 30 May 2020).

27. Hantel, A.; Abel, G.A.; Siegler, M. Practical allocation system for the distribution of specialised care during cellular therapy access scarcity. J. Med. Ethics 2019, 45, 532-537. [CrossRef]

28. Samik, U.; Yu, J.X.; Cristina, O.; Megan, H.; Jeffrey, H.; Hubbard-Lucey, V.M. Impact of COVID-19 on oncology clinical trials. Nat. Rev. Drug Discov. 2020, 19, 376-377. [CrossRef]

29. Weinkove, R.; McQuilten, Z.K.; Adler, J.; Agar, M.R.; Blyth, E.; Cheng, A.C.; Conyers, R.; Haeusler, G.M.; Hardie, C.; Jackson, C.; et al. Managing haematology and oncology patients during the COVID -19 pandemic: Interim consensus guidance. Med. J. Aust. 2020, 212, 481-489. [CrossRef]

30. Kutikov, A.; Weinberg, D.S.; Edelman, M.J.; Horwitz, E.M.; Uzzo, R.G.; Fisher, R.I. A War on Two Fronts: Cancer Care in the Time of COVID-19. Ann. Intern. Med. 2020, 172, 756-758. [CrossRef]

31. Schrag, D.; Hershman, D.L.; Basch, E. Oncology Practice During the COVID-19 Pandemic. JAMA 2020, 323, 2005-2006. [CrossRef] [PubMed]

(C) 2020 by the authors. Licensee MDPI, Basel, Switzerland. This article is an open access article distributed under the terms and conditions of the Creative Commons Attribution (CC BY) license (http://creativecommons.org/licenses/by/4.0/). 